\title{
Libraries on the Move: By Land, By Sea, and By Air
}

\author{
Jennifer Moore, Ph.D. and Aaron Elkins, Ph.D. \\ Texas Woman's University, Denton, TX. USA \\ Helen Boelens, Ph.D. \\ International School Library Researcher and Advisor, The Netherlands
}

\begin{abstract}
Libraries are critical to literacy development, particularly in developing nations where literacy rates are low, poverty rates are high, and resources are limited. School libraries in developing nations often suffer from inadequate resources, staffing, and facilities. Mobile libraries have been delivering resources and services via land and water routes to communities in developing nations, though their support of school children may be limited. Emerging technologies in the form of digital mobile libraries offer the potential to bring high quality resources and services to schools and communities. In this paper, the authors discuss/explore myriad mobile libraries, particularly in developing nations, the state of school library programs in developing nations, and the potential of digital mobile libraries to transcend the physical walls of libraries to better foster literacy for students and their communities.
\end{abstract}

\section{Keywords: Mobile Libraries, School Libraries, Developing Nation, Digital Libraries}

\section{INTRODUCTION}

While the word library is typically associated with a brick-and-mortar building, Johnson (2015) states that "librarians have a long history of overcoming geographic, economic and political challenges to bring the written word to an eager audience" (p. 7); one way librarians accomplish this goal is through the implementation of mobile libraries. The International Federation of Library Associations and Institutes (IFLA) defines mobile library as "any library service that does not stay in one place" with the intent to "promote equity of service provision by enhancing the opportunity of access to library services" (2010, $p$. 5). Mobile libraries have and currently exist in myriad forms, including but not limited to motorized land vehicles, animals, boats, rickshaws, bicycles, and more recently through digital means.

Multiple factors can drive the need for a mobile library: climate, governmental support, budget, cost, available resources, terrain, and population served (Atuti, 1999; IFLA, 2010). Traditionally, mobile libraries have served remote, rural areas where building a brick-and-mortar structure is not feasible (International Librarians Network, 2015). Mobile libraries are also deployed in underserved urban areas (Cheunwattana, 2003). The served communities are generally described as having both high illiteracy and poverty rates (Vance, 2007; Ruiz-Grossman, 2016).

As a brick-and-mortar library houses resources in multiple formats, so do mobile libraries, facilitating access to physical and electronic resources. Services and materials offered by mobile libraries vary based on the needs of the community and the availability of resources (IFLA, 2010). With the advent of smartphones and the increased access to digital resources they provide, new possibilities exist for providing library resources and services remotely, and library programs internationally are embracing the challenge (Meier, 2015).

Typically mobile libraries are used to extend the services offered by public libraries, although the literature acknowledges some cases where mobile libraries are used to provide outreach to schools (International Librarians Network, 2015). This paper provides an overview of mobile libraries worldwide 
and explores how libraries can use mobile technology to transcend their physical walls, fostering community literacy and promoting student academic achievement.

\section{By Motorized Land Vehicles}

\section{BY LAND}

Motorized land vehicle mobile libraries are better at providing rapid transport of materials, and they are able to convey larger quantities of materials than other types of mobile libraries. Three primary forms of motorized land vehicle mobile libraries exist: bookmobiles, motorbikes, and trains. Bookmobiles are the most common, and are usually in the form of a van, bus, or truck. Bookmobiles have a decades-long history of use, providing resources for patrons in rural areas of developed and developing countries. While not every country that deploys bookmobiles keeps statistics, there were 659 bookmobiles in the United States in 2014 (American Library Association, 2017).

The library resources, programs, and services provided by motorized land vehicle libraries vary greatly. The Malaika Mobile Library in Kampala, Uganda is only able to transport a small collection of physical books via motorbike (Ruiz-Grossman, 2016). The Mali Library Wagon, a train, offers a collection of 3,000 books and 300 audiovisual materials (Lucas, 2002). Specific library programs in other countries, such as Thailand, China, Canada, and Mali offer programming and services in the forms of storytime, games, activity packets, performances, summer and after school reading groups, tutoring, teaching assistance, and training (Lucas, 2002; Cheunwattana, 2003; Sanoma, 2011; Slobodian, 2014). Zimbabwe's "Big Blue," a bookmobile, offers students access to a computer lab and internet (Lucas, 2002). In the United States, OverDrive's bookmobile is strictly digital, providing eBooks, audiobooks, streaming video, and Wi-Fi access (OverDrive, n.d.). The Moska Mobile Library in Afghanistan provides books to children in remote areas and also focuses on delivering books to adolescent girls sequestered to their homes during puberty (ISHK/Hoopoe Books, n.d.). In addition to providing library resources, programs, and services, motorized land vehicle libraries may also be used for outreach to advocate for the importance of libraries (Lucas, 2002; Cheunwattana, 2003; Witteveen, 2017).

The locations visited and duration of stay by motorized land vehicle libraries varies considerably. In Bulawayo, Zimbabwe the bookmobile visits shopping centers, retirement homes, and schools for only one hour per week (Doust, 1999), while Mali's Library Wagon stops for one or two days during each visit (Lucas, 2002). Strathcona County in Canada visits schools and community centers weekly (Slobodian, 2014). The KONE Corporation Centennial Foundation's bookmobile serves migrant children living in the eastern and southern regions of China, visiting 10 cities annually, staying one to two weeks in each location (Sanoma, 2011).

While motorized land vehicle mobile libraries provide great benefits to the populations they serve, they are not without their issues. The demand for resources is often far greater than supply, even with the motorized land vehicle mobile libraries' capacity to transport hundreds or thousands of books (Doust, 1999). Motorized vehicles require maintenance and repair (Atuti, 1999) and need fuel to run (Mamyoto \& Mutasa, 2004). The vehicles also require adequate roads (or rails) to reach their destinations, need staff to operate them, and materials to offer patrons (Doust, 1999). All of these considerations require funding that is not always available, negatively affecting people's access to library resources, programs, and services.

\section{By Animals}

Mobile libraries using animals for transport (or as Vance (2007) proposes, animal-assisted libraries) have an even longer history than motorized land vehicle mobile libraries: The first recorded mobile library, England's Warrington Perambulating Library, used a horse drawn carriage in 1858 (International Librarians Network, 2015). Animal-assisted libraries typically serve patrons residing in locations not accessible by motorized land vehicle mobile libraries, because they are either too remote or the terrain is impassable for traditional vehicles. Animal-assisted libraries also serve nomadic patrons with migratory patterns, and animal-assisted libraries are more commonly found in South America, 
Africa, and Asia (Vance, 2007). Table 1 provides examples of the different species of animals used with their associated countries, but the list is not exhaustive.

Table 1: Methods of Animal Transport by Country

\begin{tabular}{|l|l|}
\hline Country & Animals Used \\
\hline Columbia & Donkey (Meier, 2015) \\
\hline Ethiopia & Donkey (Blunt, 2009; Slobodian, 2014) \\
\hline Indonesia (Java Island) & Donkey (Alfred, 2015) \\
\hline Kenya & Camel caravans (Lucas, 2002) \\
\hline Laos & Elephant (Meier, 2015) \\
\hline Mongolia & Camels, horses, cows, or reindeer (Meier, 2015) \\
\hline Peru & Horse and mule (Vance, 2007) \\
\hline Thailand & Elephant (Cheunwattana, 2003; Vance, 2007). \\
\hline Venezuela & Donkey (Slobodian, 2014) \\
\hline Zimbabwe & Donkey (Vance, 2007) \\
\hline
\end{tabular}

The use of animal-assisted libraries grants librarians and related staff the opportunity to encourage reading, facilitate literacy development, and increase information access to traditionally underserved populations worldwide, particularly in remote regions that are difficult to access, or where motorized vehicle transportation is cost prohibitive. Animal-assisted libraries facilitate access to resources, programs, and services including print, audio-visual materials, computers, internet, storytime, instruction, and hands-on activities (Vance, 2007). Thailand's now defunct Books-by-Elephant program provided electricity generators and satellite dishes in addition to print and audio-visual resources (Cheunwattana, 2003; Vance, 2007). Zimbabwe's Rural Libraries and Resources Development Programme utilized a solar-powered generator to provide "telephone, fax, email, Internet access, radio, and television capabilities" (Vance, 2007, p. 51).

Animal-assisted libraries have different issues than do motorized land vehicle mobile libraries. The animals may require time off during their mating season, narrowing the window of an animal-assisted library's availability. In general, the climate, geographical conditions, and size of the service area can be prohibitive to travel, even for animals. Just as motorized land vehicle mobile libraries require skilled workers to provide maintenance, animal-assisted libraries require skilled workers training to properly care for the animals; training that may be difficult to receive. Although animal-assisted libraries may require less funding than motorized vehicle mobile libraries, limited funds can still shut down a program, as was the case with Thailand's Books-by-Elephant program (Vance, 2007).

\section{By Humans}

Humans, with the assistance of bicycles and tricycles pulling carts and rickshaws, also provide mobile library services. With Thailand's Door-to-door box project, a 'librarian' (who may or may not be certified) transports boxes of books via tricycle, leaving one box at each home for one month, then returning to transport each box to a different home (Zabed Ahmed, 2010). Regions of Bangladesh use bicycles with rickshaws to distribute books in rural areas. In the Naogaon district of Bangladesh, police officers are required to operate the mobile libraries and visit three schools weekly, providing a variety of texts to supplement student learning (Karmaker, 2016). In the Munshiganj district, the local government disseminates books to 68 of 69 unions to encourage reading but also to educate children about societal issues such as "drug addiction, child marriage, and abnormal population growth" (Mirza, 2015). In an effort to "improve[s] the quality of life for women and their families in some of Afghanistan's most vulnerable, marginalized female-headed households" (ISHK/Hoopoe Books, n.d.), Hoopoe's Books for Afghanistan project in partnership with the Children's Book Foundation distributes hundreds of books via one man and his bicycle riding around the Bamyan province.

Even in the United States, book bike libraries are becoming popular. Book bike libraries include a bicycle or tricycle pulling a cart, offering resources and services, including physical book circulation, 
Wi-Fi access, library account registration, e-book downloading, teaching, outreach, and advocacy in Chicago, Denver, Seattle, and Oakland (Francis, 2014; Oakland Public Library, n.d.). The Dallas Public Library system intends to customize each book bike's collection for each visit's specific audience, such as schools and senior centers (Downs, 2017).

A bicycle, tricycle, cart, and rickshaw cannot carry very many materials, and while it may be minimal and relatively inexpensive, they will still require maintenance. Non-motorized vehicle libraries will also have a more limited range compared to motorized vehicle or animal-assisted libraries.

\section{BY WATER}

Mobile libraries traveling via water serve coastal, river, and canal communities, and have been in service since at least the 1950's when countries such as Sweden, Norway, and Thailand used boats to circulate books to communities (Atuti \& Ikoja-Odongo, 1999; Cheunwattana, 2003). Thailand discontinued their floating libraries for a time, but then brought them back and modernized them to include audio resources, video resources, toys, games, and computers (Cheunwattana, 2003). The purpose of these floating libraries is to "promote reading and water conservation and environmental education through books, toys and exhibitions" (Lucas, 2002, 35) and to provide educational opportunities (Lerdsuriyakul, 2000; Cheunwattana, 2003).

In West Sulawesi, Indonesia, where access to reading materials is often limited to one community copy of the Quran and literacy levels are extremely low, a journalist developed a Perahu Pustaka, a small sailboat used as a book boat, to deliver children's books written in both Indonesian and "broken English" to promote reading for pleasure (Sutcliffe, 2017). As previously mentioned, in the Munshigani district of Bangladesh, books are disseminated to 68 out of 69 unions via rickshaw; the remaining union is surrounded by a river and receives materials via a boat library, as the local government recognizes people in all unions need access to information about social issues (Mirza, 2015).

As with motorized land vehicles, mobile boat libraries service a variety of locations and remain for different durations. Indonesia's Perahu Pustaka (Book Boat) circulates approximately 4000 books with frequency dependent upon funding (Sutcliffe, 2017). Norway's Epos ship circulates 6000 books to 150 small coastal communities but only during the winter months, with the duration of each tour being 45 days, as the ship is repurposed for tourists during summer months (Bokbaten Epos, n.d.). As of 2000, Thailand's mobile boat library "served at least 30,000 people annually during, at least, five days a week" (Lerdsuriyakul, 2000).

Mobile boat libraries, like their land vehicle counterparts, suffer from wear-and-tear (Cheunwattana, 2003). Funding is also an issue, as Indonesia's journalist-run Perahu Pustaka (Book Boat) relies on donations (Sutcliffe, 2017). What effects climate change may have on the navigability of the waterways currently used by mobile boat libraries is at this time unknown.

\section{BY AIR}

While delivery of print resources through drones or other modes of air transportation is not yet a widely-reported phenomenon, balloons are being used to provide internet access in remote and rural areas in Peru (Dupere, 2017). All wireless internet transmissions travel through the air, facilitating people's access to resources through mobile devices, also known as the mobile web. As data transmission speeds increase, as the cost of connectivity decreases, and as the technological capabilities of cell phones and other mobile devices improve, people are increasingly using their mobile devices to access information through the mobile web. Librarians may capitalize on people's increased internet access to better serve the needs of their communities by utilizing new technology (Vassilakaki, 2014) to reach broader audiences and by providing better digital access to library resources and services. Thus a new form of mobile library has emerged: the digital mobile library. To be successful, a true digital mobile library must transcend a simple web presence that provide only basic library information, such as contact information, location, and links to outside websites: They must provide resources and services comparable to ones that patrons would have access to in a physical library (Fernandez, 2015), including 
database access, OPAC access, course reserves, virtual reference services, e-books, audiobooks, streaming media, and online instructional materials (Callow \& England, 2011; Bomhold, 2014; Negi, 2014; Fernandez, 2015).

As with physical mobile libraries, digital mobile libraries are not without problems: platform compatibility issues, e-books not opening or not downloading on certain devices, infrastructure expenses, determining technological priorities, and staff training are all considerations that must be met (Callow \& England, 2011). While the cost of mobile devices continues to fall, they may still be out of the range of affordability for some. Most importantly, digital mobile libraries cannot succeed if the internet infrastructure is unavailable (Fernandez, 2015), though the balloon-facilitated internet may be one way to circumvent that issue.

Extreme discrepancies exist in internet usage, internet access, and internet affordability between developed nations and developing nations. Approximately $47 \%$ of the world's population uses the internet, which means the remaining $53 \%$ do not, whether by choice or lack of access. Non-users are found predominately in Africa (75\%), the Arab States (58.4\%), and Asia (58.1\%). Although subscriptions to broadband are continually increasing in developing nations, the cost remains significantly higher than in developed nations, often to the point of unaffordability; slower bandwidth impedes access to the full range of resources and services available through the internet (International Telecommunications Union, 2016). Fernandez (2015) proposes that "Libraries could even drive into communities to loan mobile hotspots, along with a tablet that would make that device meaningful. By bringing technology to communities, libraries can take the old idea of the traveling library and combine it with whatever new innovations the libraries provide" (p. 6).

SpaceX, Facebook, and Google's X are experimenting with a variety of technologies to provide internet service in underserved areas. SpaceX intends to provide high-speed, cable-less internet access by launching 4,425 satellites between 2019 and 2024 (Kharpal, 2017). X's Project Loon, advertising "balloon-powered internet for everyone," has been using a network of balloons to transmit internet access from existing telecommunications providers to ground areas outside the covered networks. Their goal is to "... connect people in rural and remote areas, help fill coverage gaps, and bring people back online after disasters" (X, n.d.). Facebook's Connectivity Lab seeks to provide "affordable internet access...in communities around the world," with possible technologies of "high-altitude long-endurance planes, satellites and lasers" (Facebook, 2017). Creating an internet network infrastructure that is not wholly reliant on fixed physical assets will go a long way towards facilitating true access anywhere for everyone.

\section{IMPLICATIONS FOR SCHOOL LIBRARIES}

Most mobile libraries are an outreach effort of public libraries and thus serve general communities; rarely does the literature reference mobile libraries solely serving schools or acting as a supplement to school library programming or school library curriculum. In this extensive literature review, mobile libraries serving schools were only referenced in Magdalena, Columbia with the biblioburros (Ruffins, 2010) and in Zimbabwe with a standard bookmobile (Mamyoto \& Mutasa, 2004) and with the "Big Blue" bookmobile (Lucas, 2002).

School library programs, particularly those in developing nations, are a crucial component to literacy development. Exploration of related literature reveals the following commonalities among developing countries, where poverty and illiteracy rates are high, underscoring the necessity of access to libraries that can facilitate community development and improvement:

- Resources: Limited funding and the expense of importing books results in insufficient resources. Students often have no books at home (Blunt, 2009) and few books at school (Lucas, 2002; Sturges, 2004; Blunt, 2009; Nengomasha, Uutoni, \& Yule, 2012; Sutcliffe, 2017). As a result, students have no or very limited access to print materials (Nengomasha, Uutoni, \& Yule, 2012). Because so much of the developing world has no internet access for varying reasons (International Telecommunications Union, 2016), access to technological devices and the internet is insufficient (Nengomasha, Uutoni, \& Yule, 2012; Slobodian, 2014) to meet the students' needs 
for materials. The cost of books in developing countries is often quite expensive, so schools must often rely on donated materials. Unfortunately, donated materials are often not written in students' native languages; they may be outdated, unrelated to the curriculum, or irrelevant to students' personal interests; and may be of poor quality (Doust, 1999; Mamyoto \& Mutasa, 2004; Blunt, 2009; Adeyemi, 2010; Anderson \& Matthews, 2010; Nengomasha, Uutoni, \& Yule, 2012). As a result, pleasure reading is not a common activity (Doust, 1999).

- Staffing: School libraries in developing countries are often inadequately staffed. Three situations are common: the library is not staffed, a classroom teacher is assigned to perform library duties in addition to their teaching duties, or an employee is dedicated to the library but has not received library-related training (Sturges, 2004; Doust, 1999; Nengomasha, Uutoni, \& Yule, 2012).

- Facilities: In some instances, physical space is problematic. Either there is no library (Sturges, 2004), the library is in a state of decay (Sutcliffe, 2017), or the physical space is extremely small, often limited to a storeroom within the school (Nengomasha, Uutoni, \& Yule, 2012).

School Libraries Work (Scholastic Library Publishing, 2016), a seminal work in the American school library field, concludes that "A credentialed school librarian, collaboration and co-teaching, technology access, and collection size all elevate student learning" (2016, p. 1). In developing nations, school libraries with insufficient and irrelevant resources, insufficient and/or untrained staff, and inadequate facilities are more common than not, making it incredibly difficult to raise literacy rates and improve academic achievement. Mobile libraries, in their myriad forms, provide partnership opportunities to support curricular and personal reading and information needs, as well as technology and internet access, although they suffer from some of the same issues as school libraries, with limited resources, limited funding, inconsistent access, and potentially untrained staff.

The emergence of digital mobile libraries, with the prospect of inexpensive or free high speed internet reaching into all corners of developing nations (Kharpal, 2017; X, n.d.; Facebook, 2017), and the development of mobile friendly library resources and services (Callow \& England, 2011; Vassilakaki, 2014; Fernandez, 2015) may bridge the existing gaps, allowing children everywhere to have sufficient access to high quality, current, accurate, and relevant information. Digital mobile libraries can transcend the four walls of the physical school library, enabling children to become judicious consumers and creators of information, and improve literacy rates for all peoples in developing countries.

Some questions about the effects and implementation of mobile libraries, digital information access, and school libraries in developing countries are yet to be answered, as scholarly research in these areas is limited. In the absence of abundant resources, how well are mobile libraries supporting community needs and working to improve literacy? To what extent are mobile libraries serving children? To what extent are mobile libraries supporting schools and school library programs? What mobile library strategies are the most effective and produce the best outcomes? What else can be done to increase access to quality resources, programs, and services?

\section{CONCLUSION}

Mobile libraries are one way to offer information access and opportunities for literacy development in areas where it is not feasible to build brick-and-mortar libraries. In developing nations, mobile libraries often serve communities with high poverty rates and low literacy rates. Schools in these developing nations often either do not have libraries, or have libraries with untrained staff, insufficient funding, and/or irrelevant, outdated collections. Rarely, however, are mobile libraries targeted towards specifically supporting school library programs. Emerging technologies are changing the face of information provision and access, offering opportunities for the transformation of physical mobile libraries into digital mobile libraries that can empower students and communities by fostering the development of traditional and information literacies.

\section{REFERENCES}


Adeyemi, T. O. (2010). The school library and students' learning outcomes in secondary schools in Ekiti State, Nigeria. Asian Journal of Business Management, 2(1), 1-8.

Alfred, C. (2015, May 8). How one man and his horse created a mobile library in Indonesia. Huffington Post. Retrieved May 10, 2017 from http://www.huffingtonpost.com/2015/05/08/mobile-libraryhorse-indonesia_n_7242042.html

American Library Association. (2017). Bookmobiles in the U.S. Retrieved May 16, 2017 from http://www.ala.org/research/librarystats/public/bookmobiles/bookmobilesu

Anderson, J., \& Matthews, P. (2010). A Malawian school library: culture, literacy and reader development. Aslib Proceedings, 62(6), 570-584.

Atuti, R. (1999). Camel library service to nomadic pastoralists: The Kenyan scenario. IFLA Journal, 25(3), 152-158.

Atuti, R., \& Ikoja-Odongo, J. (1999). Private camel library brings hope to pastoralists: The Kenyan experience. Library Review, 48(1), 36-42.

Blunt, E. (2009, January 8). Donkeys boost Ethiopian literacy. BBC News. Retrieved May 1, 2017 from http://news.bbc.co.uk/2/hi/africa/7777560.stm

Bokbaten Epos. (n.d.). The library boat. Retrieved May 18, 2017 from http://bokbaten.no/informationin-english/

Bomhold, C. (2014). Mobile services at academic libraries: Meeting the users' needs? Library Hi Tech, 32(2), 336-345.

Callow, M., \& England, K. (2011). Preparing your library for mobile devices. m-libraries Conference, 11-13 May. Retrieved May 2, 2017 from https://eprints.usq.edu.au/19095/1/Callow_England_mlibraries 2011 AV.pdf

Cheunwattana, A. (2003). Mobile and outreach library services in Thailand. Information Development, 19(1), 23-27.

Doust, R. (1999). Provisions of school library services by means of mobile libraries: The Zimbabwe experience. IFLA Journal, 25(3), 148-151.

Downs, C. (2017, January 7). Dallas Public Library hopes 'bookbike' is just the first of fleet to soft-pedal literacy. Dallas News. Retrieved January 8, 2017 from https://www.dallasnews.com/news/dallas/2017/01/07/dallas-public-libary-hopes-bookbike-justfirst-fleet-soft-pedal-literacy

Dupere, K. (2017, May 19). This balloon-powered internet is helping Peru during extreme floods. Mashable. Retrieved May 19, 2017 from: http://mashable.com/2017/05/18/project-loon-perugoogle-internet/\#5Nb_ZsMWf8qE

Facebook. (2017). Connectivity Lab. Retrieved May 22, 2017 from https://info.internet.org/en/story/connectivity-lab/

Fernandez, P. (2015). Through the looking glass: Envisioning new library technologies' mobile libraries, beyond the Website. Library Hi Tech News, 32(3), 5-8.

Francis, C. (2014, August 3). Custom library book bikes roll out across US. American Libraries. Retrieved May 2, 2017 from https://americanlibrariesmagazine.org/2014/08/13/custom-librarybook-bikes-roll-out-across-us/

International Federation of Library Associations and Institutes. (2010). Mobile library guidelines. Retrieved May 3, 2017 from https://www.ifla.org/files/assets/hq/publications/professionalreport/123.pdf

International Librarians Network. (2015). Different libraries around the world: Mobile library. Retrieved May 16, 2017 from http://interlibnet.org/2015/03/26/different-libraries-around-the-world-mobilelibrary/

International Telecommunications Union. (2016). ICT facts and figures 2016. Retrieved May 22, 2017 from http://www.itu.int/en/ITU-D/Statistics/Documents/facts/ICTFactsFigures2016.pdf

ISHK/Hoopoe Books. (n.d.) Latest news. Hoopoe Books for Afghanistan. Retrieved May 14, 2017 from http://booksforafghanistan.org/news/ 
Karmaker, K. (2016, May 28). Mobile libraries at doorsteps enlightening Naogaon people. The Daily Star. Retrieved May 9, 2017 from http://www.thedailystar.net/city/mobile-libraries-doorstepsenlightening-naogaon-people-1230628

Kharpal, A. (2017, May 4). Elon Musk's SpaceX plans to send the first of its 4,425 super-fast internet satellites into space in 2019. CNBC. Retrieved May 17, 2017 from http://www.cnbc.com/2017/05/04/spacex-internet-satellites-elon-musk.html

Lerdsuriyakul, K. (2000). Telling the mobile libraries story: Collecting the past to build a future. 66th IFLA Council and General Conference Jerusalem, Israel, 13-18 August. Retrieved May 5, 2017 from https://archive.ifla.org/IV/ifla66/papers/102-175e.htm

Lucas, S. (2002). Mobile libraries: Where the schools are going to the students. TechKnowLogia, 34-37. Retrieved May 3, 2017 from http://lib.icimod.org/record/10939/files/4259.pdf

Mamvoto, P. \& Mutasa, M. (2004). The library as a tool for development: The case of Zimbabwe. Paper presented at the 70th IFLA General Conference and Council, Buenos Aires, Argentina, August 22-27. Retrieved May 4, 2017 from https://archive.ifla.org/IV/ifla70/papers/083eMamvoto_Mutasa.pdf

Meier, A. (2015, May 13). The nomadic libraries bringing books to the four corners of the globe. Hyperallergic. Retrieved May 3, 2017 from https://hyperallergic.com/202030/the-nomadiclibraries-bringing-books-to-the-four-corners-of-the-globe/

Mirza, F. (2015, December 19). Mobile library for kids. The Daily Star. Retrieved May 9, 2017 from http://www.thedailystar.net/backpage/mobile-library-kids-189391

Negi, D. (2014). Using mobile technologies in libraries and information centers. Library Hi Tech News, 31(5), 14-16.

Nengomasha, C., Uutoni, W., \& Yule, W. (2012). The impact of school libraries on learning and academic achievement. International Journal of Information Processing and Communication, l(1), 120-138.

Oakland Public Library. (n.d.). Bike library. Retrieved May 15, 2017 from http://oaklandlibrary.org/services/bike-library

OverDrive, Inc. (n.d.). Digital Bookmobile. Retrieved May 14, 2017 from http://digitalbookmobile.com/

Ruffins, E. (2010, February 26). Teaching kids to read from the back of a burro. CNN. Retrieved May 5, 2017 from http://www.cnn.com/2010/LIVING/02/25/cnnheroes.soriano/

Ruiz-Grossman, S. (2016, May 13). This mobile library delivers books to kids in need via motorcycle. Huffington Post. Retrieved May 4, 2017, from http://www.huffingtonpost.com/entry/malaikamobile-library-uganda-motorcycle_us_57338479e4b0436a18b5b6aa

Safi, B. (2017, April 3). Coming together to rebuild Afghanistan. Fair Observer. Retrieved May 1, 2017 from https://www.fairobserver.com/region/central south asia/afghanistan-politics-economysecurity-south-asia-news-76000/

Sanoma. (2011, October 17). Mobile Library brings joy of learning to children in China. Retrieved May 18, 2017 from https://sanoma.com/en/news/mobile-library-brings-joy-learning-children-china

Scholastic Library Publishing. (2016). School libraries work! A compendium of research supporting the effectiveness of school libraries. Retrieved August 9, 2016 from http://www.scholastic.com/SLW2016/

Slobodian, C. (2014). Rural library services for children. Retrieved May 4, 2017 from https://era.library.ualberta.ca/files/wh246s47c\#.WRYKf1TyuMo

Sturges, P. \& Neill, R. (2004). E-book. The quiet struggle: Information and libraries for the people of Africa. $\left(2^{\text {nd }}\right.$ ed.). London, England: Routledge.

Sutcliffe, T. (2016, October 21). A library that brings books by sailboat. BBC. Retrieved May 16, 2017 from http://www.bbc.com/travel/story/20161013-a-library-that-brings-books-by-sailboat

Vance, J. (2007). Animal-assisted librarianship: Delivering books to remote readers. International Journal of the Book, 4(2), 49-53.

Vassilakaki, E. (2014). Mobile information services in libraries: A review of current trends in delivering information. Interlending \& Document Supply, 42(4), 176-186. 
Whitteveen, A. (2017, April). Hot wheels. School Library Journal, 63(4), 34-37.

X. (n.d.). What Is Project Loon. Retrieved May 22, 2017 from https://x.company/loon/

Zabed Ahmed, S. M. (2010). Measuring performance and impact of rural community-led library initiatives in Thailand. Information Development, 26(1), 17-35. 